proposals for nutrition research from public-private collaborations. Companies and public-sector organizations could set up staff exchange programmes. And executive-level courses, either at universities or in private institutions, could bring together professionals from both sectors to learn from instructors drawn from these two worlds.

Many analysts (myself included, in the past) have drawn parallels between 'big tobacco' and 'big food'. In both cases, major corporations wield immense power over consumers and society, and their products are capable of doing considerable harm.

But there are crucial differences. Unlike big tobacco, big food is not the only player. There are small- and medium-sized companies too. And big tobacco cannot make tobacco that promotes public health, whereas big food can and does produce nutritious, sustainable foods. Motivated by both carrots and sticks, the industry can produce more - at a lower price.

Lawrence Haddad is executive director of the Global Alliance for Improved Nutrition (GAIN) in Geneva, Switzerland.

e-mail:lhaddad@gainhealth.org

1. Briggs, A. D. M. et al. Lancet Public Health 2, e15-e22 (2017)

2. Nakhimovsky, S. S. et al. PLOS ONE 11, e0163358 (2016).

3. Colchero, M. A., Rivera-Dommarco, J., Popkin, B. M. \& Ng, S. W. Health Aff. 36, 564-571 (2017)

4. Save the Children. Don't Push It: Why the Formula Milk Industry Must Clean Up Its Act (Save the Children, 2018)

5. Cairns, G., Angus, K., Hastings, G. \& Caraher, M. Appetite 62, 209-215 (2013)

6. Afshin, A. et al. PLoS ONE 12, e0172277 (2017).

7. World Health Organization. Global Nutrition Policy Review 2016-2017 (DRAFT). (WHO, 2018).

8. International Food Policy Research Institute. Global Nutrition Report 2016: From Promise to Impact: Ending Malnutrition by 2030 (IFPRI, 2016)

9. Alexander, E., Yach, D. \& Mensah, G. A. Glob. Health 7, 26 (2011).

10.Turner, T., Spruijt-Metz, D., Wen, C. K. F. \& Hingle, M. D. Pediatr. Obes. 10, 403-409 (2015).

11.University of Sydney Impact Evaluation Consortium for Global Alliance for Improved Nutrition. Effectiveness of an Integrated Program to Reduce Maternal and Child Malnutrition in Indonesia: Cross-Sectional Impact Evaluation Report (Global Alliance for Improved Nutrition, 2017)

12.Lipinski, B. et al. Reducing Food Loss and Waste. Working Paper (World Resources Institute, 2013).

13.Altai Consulting. USAID-GAIN Case Study Annex to Technical Report on the MNF Assessment (USAID/GAIN, 2016)

14.Cecchini, M. \& Warin, L. Obes. Rev. 17, 201-210 (2016).

15. Iannotti, L. L. et al. Pediatrics 140, e20163459 (2017).

16. Hoddinott, J. F., Gillespie, S. \& Yosef, S. World Rev. Nutr. Diet. 115, 233-238 (2016)

17.Gornall, J. Br. Med. J. 350, h231 (2015).

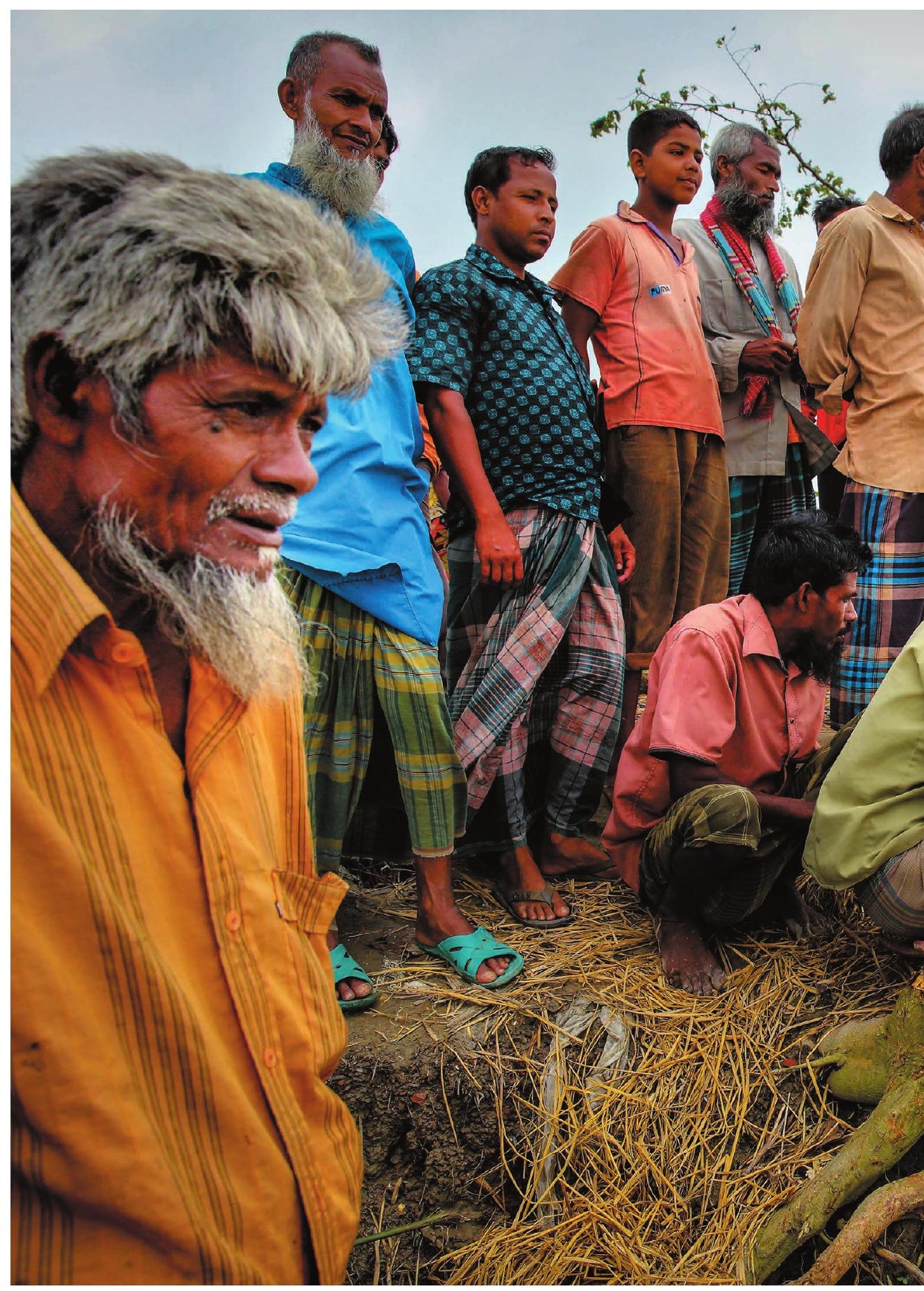

\section{Developing countries must lead on solar}

\section{geoengineering research}

The nations that are most vulnerable to climate change

must drive discussions of modelling, ethics and governance, argue A. Atiq Rahman and colleagues. 
benefit many regions that are vulnerable to climate change, with few losers. Monsoon rains would be affected less than if climate change proceeds unchecked ${ }^{9}$.

But solar geoengineering is no panacea; it could compound some risks of climate change. It would only mask the warming effect of greenhouse gases. Ocean acidification would still pose a threat to marine life if carbon-dioxide emissions were not slashed. Sulfur dioxide might delay ozone regeneration in the stratosphere. And whichever aerosol was used to filter out sunlight, more research would be needed on its impacts on health and the environment.

The overall effects of solar geoengineering are uncertain. All studies so far are based on computer simulations, which are poor at forecasting regional climates, for example. The Earth system might hold surprises that digital models do not capture. The projections require thorough and sceptical examination.

Furthermore, solar geoengineering raises difficult socio-political issues that cannot be wished away. It is uncertain how, or whether, the technique could be governed in ways that ensure prudence, accountability and justice. Who has the right to implement an inherently global technology? Would the technology weaken multilateral commitments to reduce emissions such as the Paris agreement?

These issues matter deeply to developing nations. But most solar-geoengineering research is being done in the well-heeled universities of Europe and North America. Unless that changes, voices from the global north will set the policy agenda and decide which research projects should be accelerated or shut down.

We are neutral on whether solar geoengineering should ever be used. It has not yet been established whether it would be a beneficial addition to meeting the Paris goals. We recognize its potential physical risks and socio-political implications. And we oppose its deployment until research into its safety and effectiveness has been completed and international-governance mechanisms established. But we are committed to the co-production of research and to wellinformed debate.

Others have already taken sides. Some people in the global north have tried to convince their peers in the south that they should reject solar geoengineering. Campaigners who vehemently oppose it often make their case by emphasizing the risks and playing down the potential benefits ${ }^{10}$. We take issue with this paternalism and propose an inclusive way forward.

\section{BIG DECISIONS}

Developing countries must be in a position to make up their own minds. Local scientists, in collaboration with others, need to conduct research that is sensitive to regional concerns and conditions. For example, what effects might solar geoengineering have on hurricanes in the Caribbean, flooding in Bangladesh or agriculture in East Africa? Broader discussions among academics, policymakers, the public and public intellectuals are needed on climate risks and justice.

To begin this process, we (and the co-signatories of this Comment) have been running solar-geoengineering engagement workshops across the global south - the first of their kind - as part of the SRM Governance Initiative (SRMGI), in which SRM stands for solar radiation management. International and non-governmental, SRMGI was launched in 2010 by the Royal Society in London, "Solar The World Acadgeoengineering emy of Sciences raises difficult (TWAS) in Trieste, socio-political Italy, and the Enviissues that ronmental Defense Fund in New York wished away," City. The regional workshops - held mostly in the past three years in Bangladesh, Brazil, China, Ethiopia, India, Jamaica, Kenya, Thailand, New Zealand (for the Pacific states), Pakistan and the Philippines - have brought together local climate scientists, journalists, policymakers and representatives of civil society to learn about and discuss solar geoengineering.

Participants had no consensus position on the technology. But they raised common hopes and concerns. In general, we found widespread opposition to deployment at this stage, but support for studies of local impacts. As a participant at the Nairobi workshop put it: "This idea is crazy ... but we have to understand it." Many were sceptical about whether the methods would work and if developing countries, rather than more powerful governments, would have any say in how and whether solar geoengineering is deployed.

To fund regional research, this week, SRMGI issues the first call for applications to a US $\$ 400,000$ fund called Developing Country Impacts Modelling Analysis for SRM (DECIMALS). The fund is administered by TWAS and financed by the Open Philanthropy Project, a foundation backed by Cari Tuna and Dustin Moskovitz (co-founder of Facebook and the project-management app Asana). Developing-world scientists can apply to DECIMALS for funds to model the solar-geoengineering impacts that matter most to their regions. International collaborations will be supported and researchers will be asked to run local workshops to promote wider discussion of the implications of their findings.

Further outreach and research in the developing world will require extra support from governments, universities and civil society worldwide. Research funders in advanced economies should fund collaborations with scientists in developing countries. We would like to see an IPCC special report on the risks and benefits of solar geoengineering. Ultimately, a coordinated global research initiative - perhaps under an organization such as the World Climate Research Programme - is needed to promote collaborative science on this controversial issue.

Solar geoengineering is fraught with risks and can never be an alternative to mitigation. But it's unclear whether the risks of solar geoengineering are greater than the risks of breaking the $1.5^{\circ} \mathrm{C}$ warming target. As things stand, politicians will face this dismal dilemma within a couple of decades. It is right, politically and morally, for the global south to have a central role in solargeoengineering research, discussion and evaluation.

A. Atiq Rahman is executive director of the Bangladesh Centre for Advanced Studies, Dhaka, Bangladesh. Paulo Artaxo is professor of environmental physics, Institute of Physics, University of São Paulo, São Paulo, Brazil. Asfawossen Asrat is professor of geology, School of Earth Sciences, Addis Ababa University, Addis Ababa, Ethiopia. Andy Parker is project director of the Solar Radiation Management Governance Initiative and honorary senior research fellow, School of Earth Sciences, University of Bristol, Bristol, UK. The authors write on behalf of 8 co-signatories. e-mail:aparker@srmgi.org A.P. declares competing financial interests.

1. Nurse, L. A. et al. Small islands. In Climate Change 2014: Impacts, Adaptation, and Vulnerability. Part B: Regional Aspects (eds Barros, V. R. et al.) 1613-1654 (Cambridge Univ. Press, 2014).

2. Hijioka, Y. et al. Asia. In Climate Change 2014: Impacts, Adaptation, and Vulnerability. Part B: Regional Aspects (eds Barros, V. R. et al.) 1327-1370 (Cambridge Univ. Press, 2014).

3. Niang, I. et al. Africa. In Climate Change 2014: Impacts, Adaptation, and Vulnerability. Part B: Regional Aspects (eds Barros, V. R. et al.) 1199-1265 (Cambridge Univ. Press, 2014).

4. Magrin, G. O. et al. Central and South America. In Climate Change 2014: Impacts, Adaptation, and Vulnerability. Part B: Regional Aspects (eds Barros, V. R. et al.) 1499-1566 (Cambridge Univ. Press, 2014).

5. Kleinschmitt, C., Boucher, O. \& Platt, U. Atmos. Chem. Phys. 18, 2769-2786 (2018).

6. Curry, C. L. et al. J. Geophys. Res. Atmos. 119, 3900-3923 (2014).

7. Moore, J. C., Jevrejeva, S. \& Grinsted, A. Proc. Natl Acad. Sci. USA 107, 15699-15703 (2010).

8. Moore, J. C. et al. Proc. Natl Acad. Sci. USA 112 13794-13799 (2015).

9. Reynolds, J., Parker, A. \& Irvine, P. J. Earth's Future 4, 562-568 (2016).

10.ETC Group. Geoengineering and Climate Change: Implications for Africa (ETC Group, 2014).

A full list of co-signatories and details of competing financial interests accompany this article online (see go.nature.com/2pjbevu). 